\title{
Kiergegaard and Nietzsche: anticipators and forerunners
}

\begin{abstract}
Kierkegaard and Nietzsche were not much recognised during their short lives. Kierkegaard was often ridiculed when he roamed the Copenhagen centre daily and Nietzsche was far from the best-seller he happen to be today. But they were forerunners to the existentialism of Sartre and Heidegger, though without sharing the Marxism of the former and the mysticism of the latter. Kierkegaard anticipated modernism (individual choice behaviour) and Nietzsche anticipated the subjectivism and perspectivism of post-modernism. Kierkegaard had another side - a kind of religious pietism- like Nietzsche, whose admiration for force and violence contradicts his admiration for Greek culture.
\end{abstract}

Keywords: modernism, post-modernism, anticipation philosophy, Kierkegaard's and Nietzsche's micro orientation
Volume 2 Issue 5 - 2018

Jan-Erik Lane
UNIGE, Switzerland

Correspondence: Jan-Erik Lane, Emeritus Professor, UNIGE, Switzerland, Email janaklane@googlemail.com

Received: August 08, 2018 | Published: September 21, 2018

\section{Kierkegaard}

\section{Introduction}

If any philosopher can be said to be ahead of their time, it should be the Dane Soren Kierkegaard and the German-Swiss Friedrich Nietzsche. ${ }^{1}$ They rejected the prevailing ideas of the first haft of the 19th century - German idealism and Kantianism. And they were out of tune with the coming analytical philosophy of the second half of the 19th century. But they anticipated major trends in 20th century philosophy and Weltanschaungen, namely individualism, indeterminism and game theory (Kierkegaard) as well as existentialism and post-modernism (Nietzsche).

These two scholars were prominent on the philosophical scene after the death of I. Kant in 1804 up to the coming of G. Frege in 1879 by means of their rejection of German idealism. Both distanced themselves from the search of "das Ding an sich" in the nation (Fichte), Schelling (Nature), the Spirit (Hegel), the will (Schopenhauer) and alienation (Marx). The Danish genius abstained from metaphysics, which Nietzsche did not succeed in despite great efforts.

Kierkegaard is today looked upon with concepts from the 20th century. How do we establish that a philosopher is "similar" to another thinker? Kierkegaard is classified with J.P. Sartre, which is very misleading, given Sartre's endorsement of a certain type of harsh Communism. Kierkegaard is also put together with F. Nietzsche, which is simply erroneous, given the latter's determinism: "eternal recurrent". Or he is regarded as a forerunner to Heidegger, which does not provide justice to him, given Heidegger's mysticism. So, what or whom is Kierkegaard similar to? Where to place him: Camus' existentialism, Christianity. Indeterminism, scepticism, etc.?

Nietzsche is even harder to place as a forerunner. There is the accusation of inspiration of fascism, but also the praise for a source of inspiration for human self-liberation and authentic expression as a true individualist against all form of collectivism and self-deceit. In post-modernist thinking, Nietzsche is highly revered, also by Left authors. His life was tragic, ending in insanity by a cause not fully known. Kierkegaard 'life is also often described as unlucky due to his unfulfilled love to promised fiancé.

\section{Kierkegaard's two sides}

S.A. Kierkegaard (1813-1855) broke with the dominant philosophical mode at the time in the first half of the 19th century, launching the rudiments of modelling individual human behaviour along lines that were formalized systematically by 20 th century game theory. ${ }^{2}$ Rejecting both German macro determinism and Kantian intellectualism, he provided new insights into human choice action and the foundation of human decisions in volitions and emotions.

Kierkegaard was deeply religious but he managed to uphold the distinction "croyance" and "savoir" in a remarkable way. Kierkegaard found no school of philosophy or theology and had not memorable students to elaborate his ideas. He was the perfect loner with one distinctive mark, the rejection of Hegelianism, right or left. What is original with Kierkegaard is not his highly emotional Christianity or his peculiar relationship with the opposite sex, especially his failed engagement to Regine Olsen, but his indeterminist philosophy.

Born in 1813, Kierkegaard enjoyed only a short period of hectic publishing, between 1843 and 1855, when death stopped him. His texts include lengthy books and shorter booklets or pamphlets besides lots of occasional newspaper publishing and personal correspondence as well as a diary. Using pseudonyms often has raised the problem of who is speaking in the books or booklets. Sometimes this may be confusing, as the text is sometimes a dialogue for and against the position that the pseudonym is presenting. In general, Kierkegaard is not easy reading, as he tends to enter into long discussion for and against an argument. Here, I will focus upon the following texts: Either-Or (1843) and Unpublished Unscientific Manuscript (1846), where his three most important tenets, in my view, are presented.

In the other books or booklets, one may find several interesting discussions, for instance about dread, fear and trembling as well as the separation between religion as institution against religion as faith. But his high ranking among philosophers stems from these three tenets. Instead, his importance to Western philosophy is to be found in three tenets, to be discussed below:

1) The Idea of Individual Choice;

2) The Asymmetry between the Past and the Present- Future; 
3) The distinction between Objectivity and Subjectivity.

Kierkegaard spent a lot of time in newspaper debates, attacking and counter-attacking his critics. He had a very poisonous pen for the established state church and its hypocrisies.

\section{Analyse of decision-making}

In political economy and public choice, one encounters very often the concept of the alternatives of action. In fact, policy analysis is often the enquiry into the set of alternatives in a policy area, spelling out the consequences of each alternative as well as their pros and cons. In the natural sciences, one does not find something similar to this framework of enquiry into action alternatives or possibilities.

The more alternatives of action there are, the higher the degrees of freedom in behaviour, Real alternatives of action entails degree of freedom, i.e. action must be unforced or voluntary. When there is only one course of action, the behaviour is deterministic. Indeterminism is the admission of alternatives of action, or degrees of freedom. ${ }^{2}$

In game theory, these concepts form the foundation for the theory of choice, or rational decision-making. The theory of choice is a micro approach to individual behaviour that is completely at odds with macro deterministic approaches to social systems. Here, we have the opposition between Kierkegaard and Hegel.

Of course, the concept of determinism is ambiguous, as different connotations have been suggested. The term "indeterminism" is even more complex and perhaps incoherent.

In Collins English Dictionary, we find a standard definition of "determinism":

"Also called: necessitarianism the philosophical doctrine that all events including human actions and choices are fully determined by preceding events and states of affairs, and so that freedom of choice is illusory."

https://www.collinsdictionary.com/dictionary/english/ determinism

One finds several other definitions of this often employed term, as when in physics strict determinism is contrasted with probabilism, particle level indeterminism and chaos states. Here, I deal only with determinism is the sense above and "indeterminism" is the opposite theory, confined to human affairs.

In political theory, the problem of free will in individual behaviour created lots of confusion, up until Kierkegaard. In the ancient philosophies like Epicurism and Stoicism, determinism was the main line, but elements of free will had to be recognized, creating lots of confusion. During the medieval period, the question of the freedom of individual behaviour was intensely debated on a religious ground of the condition for redemption, i.e. simple predestination against double predestination. Erasmus of Rotterdam became famous for his defence of free will against Luther and Calvin.

In modern secular political philosophy, the adherents of determinism are many: Hobbes, Spinoza, Holbach, Helvetius, etc. Kant tried a double solution with "two kingdoms", reserving determinism for nature and indeterminism for human behaviour. The macro philosophies of the 19th century were all deterministic, like Schopenhauer, Hegel and Marx.

It appears that the strict determinism of e.g. Hobbes and Spinoza is contradicted in their own theoretical constructs. Thus, Hobbes claims that human beings are driven by their mundane motivation to a natural state of "omnium bellum contra omnes". But then he posits a decision to create a grand contract for peace and moreover Hobbes says that there is a choice between monarchy, aristocracy and democracy. This choice is based on a deliberation by those making the covenant and it is resolved by Hobbes himself in favour of monarchy, on very shaky theoretical grounds. Is this determinism?

Similarly, the hard core determinist Spinoza enters several contradictions in his Political Treatise, where he moves from a Hobbesian state of nature, human motivation driven by enlightened egoism, often brutal, to an extended deliberation about the choice of the best "dominion" or "commonwealth" with Hobbes. "Best state' here means peace and the welfare of citizens. Spinoza makes a lengthy enquiry into a number of crucial decisions about various forms of monarchy, of aristocracy and democracy, favouring the latter on principal-agent reasons. Political choices!

\section{Alternatives of action and degrees of freedom}

Kierkegaard's great achievement is to hand down the first comprehensive analysis of human deliberation and choice, in opposition to German metaphysics, right-wing or left-wing or Schopenhauer's grandiose pessimism. Kierkegaard's philosophy of action cannot be associated with a French Marxist like J.P. Sartre; to analyse his life as an entire Freudian neurosis towards one woman ${ }^{3}$ is just not pertinent to the case. His first book -Either - Or (1843)is one of the absolute ${ }^{4}$ masterpieces in Western philosophy, to be followed up with stunning books or booklets on the dimensions of choice: anxiety, remorse, fear, trembling, subjectivity-objectivity, etc. We make a few quotations from Either-Or:

"Now in case a man were able to maintain himself upon the pinnacle of the instant of choice, in case he could cease to be a man, in case he were in his inmost nature only an airy thought, in case personality meant nothing more than to be a kobold, which takes part, indeed, in the movements but nevertheless remains unchanged ; in case such were the situation, it would be foolish to say that it might ever be too late for a man to choose, for in a deeper sense there could be no question of a choice. The choice itself is decisive for the content of the personality, through the choice the personality immerses itself in the thing chosen, and when it does not choose it withers away in consumption." 5

Kierkegaard creates a solid foundation for the analysis of human behaviour from the micro perspective, anticipating the perspective of 20th century game theory. He had visited Berlin several times, but there he found only macro metaphysics in the lectures of prominent Germans. His originality is high:

"You will perceive also in what I have just been saying how essentially my view of choice differs from yours (if you can properly be said to have any view), for yours differs precisely in the fact that it prevents cogitation involved in weighing the alternatives, not on account of the multiplicity of thoughts which attach themselves to every link in the chain, but rather because there is danger afoot, danger that the next instant it may not be equally in my power to choose, that something already hast been lived which must be lived over again. For to think that for an instant one can keep one's personality a blank, or that strictly speaking one can break off and bring to a halt the course of the personal life, is a delusion. The personality is already interested in the choice before one chooses, and when the choice is postponed the personality chooses unconsciously....". 
This emphasis upon choice has a tremendous theoretical force, with lots of implications that Kierkegaard studied in the next-coming books. We must ask what when the distinction either-or matters for human affairs. Kierkegaard replies: the future.

\section{Asymmetry between past and present or future}

The doctrine of indeterminism or voluntarism is criticized for harbouring unscientific nations like "causa sui" or events that lack conditions completely. Let us quote from The Information Philosopher:

"The core idea of indeterminism is closely related to the idea of causality. Indeterminism for some philosophers is an event without a cause (the ancient causa sui. But we can have an adequate causality without strict determinism, the "hard" determinism which implies complete predictability of events and only one possible future. We can call this "adequate determinism."

http://www.informationphilosopher.com/freedom/ indeterminism.html

In indeterminism revised, the focus is not upon "causa sui" but upon choice, alternative of action and degrees of freedom in individual decisions. This framework, elaborated in modern game theory, calls for a distinction between the past, which cannot be changed, and he present-future, where choice is feasible.

In Either-Or, Kierkegaard already anticipates this well-known distinction: between the presence and the future from an action point of view:

"As truly as there is a future, just so truly is there an either/or."

However, the famous Kierkegaard distinction is spelled out more sharply in his Journals/Notebooks, from which we render this quotation:

"It is really true what philosophy tells us, that life must be understood backwards. But with this, one forgets the second proposition, that it must be lived forwards. A proposition which, the more it is subjected to careful thought, the more it ends up concluding precisely that life at any given moment cannot really ever be fully understood; exactly because there is no single moment where time stops completely in order for me to take position [to do this]: going backwards."

Note: Kierkegaard, Journalen JJ:167 (1843), Søren Kierkegaards Skrifter, Copenhagen, 1997—, volume 18, page $306 .^{6}$

h t t p : / / homepage.math.uiowa.edu/ jorgen/ kierkegaardquotesource.html

This distinction, first made by Kierkegaard, has a strong bearing upon the solution of the paradox of determinism versus indeterminism. What he suggests is in reality some kind of ex post determinism and ex ante indeterminism, as a solution of the conundrum of causality and free will. For the past holds that one could not have acted differently, determinism, but for the future there are degrees of freedom when decision is voluntary, meaning a choice based upon deliberation.

\section{Objectivity versus subjectivity}

In the booklet Philosophical Fragments (1844), Kierkegaard debates the nature of faith in general and Christianity in particular. It falls outside of my interest here. But in a large book meant as addition, the Concluding Unscientific Postscript (1846), Kierkegaard spells out how he looks upon the philosophical problem of subjectivity contra objectivity in a fashion that is original and worth examining (Table 1).

Table I Kierkegaard's conceptual scheme

\begin{tabular}{ll}
\hline Objectivity & Subjectivity \\
\hline Objective truth & Subjective truth \\
Outside & Inside \\
Approximation & Appropriation \\
Uncertainty & Emotions, Passion \\
\hline
\end{tabular}

One talks about objective knowledge or objective truth on the one hand and subjective insights or subjective attitudes on the other hand. Can one speak of subjective truth against objective truth? Perhaps objectivity is figment of the philosopher's imagination and subjectivity is the correct position, not only in relation wishes or preferences but also faith and all beliefs? Kierkegaard develops a conceptual scheme for debating objectivity versus subjectivity:

Kierkegaard looks upon these dichotomies as a logical list on both sides, employing them to clarify what subjective Christianity would amount to. Objective Christianity does not exist. Here, Kierkegaard achieves a clear separation between belief and faith, often confused in both philosophy and theology. And his goal with these distinctions is to safeguard "Frommichkeit und Dienst":

"But the speculative philosopher views things altogether differently. He believes but only to a certain degree. He puts his hand to the plow but quickly looks about for something to know. From a Christian perspective, it is hard to see how he could reach the highest good in this manner." (Philosophical Scepticism, 270)

Kierkegaard's distinctions would hardly go down with the subjectivism of post-modernism, but sits well with modern game theory where information belongs to the right side and preferences to the left side.

\section{Nietzsche}

\section{Introduction}

The literature on Friedrich Nietzsche (1844-1900) increases with new comments and interpretations. His books are now all on the WEB. Post-modernist philosophy and social science has resulted in a fundamental re-evaluation of his ideas. Thus, the emphasis is now upon his insights into human personality and the link between psychology and dominant culture or moral ideology-the key words being emancipation, self-realization and expressiveness. Nietzsche's most original contribution is no doubt his epistemological subjectivism in a period when the dominant philosophy of science was positivistic, underlining objectivity; this perspectivism make him a major forerunner to the post-modernist revolution after the Second World War. Actually, Nietzsche is regarded as the first major philosopher of perspectivism: "There are no facts".

However, his major effort went into practical philosophy, especially moral theory, with his typical perspective of power as a dominant force in shaping culture and religion. Nietzsche is seen as the philosopher of individualism, subjectivism and personal freedom. Yet, he had no place for the idea of free will in his philosophy. Let us make a few telling quotations:

"Freedom of will and isolation of facts. - Our usual imprecise mode of observation takes a group of phenomena as one and calls it a fact: between this fact and another fact it imagines in addition 
an empty space, it isolates every fact. In reality, however, all our doing and knowing is not a succession of facts and empty spaces but a continuous flux. Now, belief in freedom of will is incompatible precisely with the idea of a continuous, homogeneous, undivided, indivisible flowing: it presupposes that every individual action is isolate and indivisible; it is an atomism in the domain of willing and knowing." $7-8$

Nietzsche adduces his Herakleitian heritage, referring to life as an endless flux of events - "panta rhei" said the great philosopher from Ephesos. No time for deliberations about ends and means of action, as life is a like a powerful stream of water, carrying everyone along in its determined course. The only comfort is the "amor fati" and the eternal recurrence. Is it really "comfort" for lower strata? Well, nothing else exists, as the freedom of will and choices after deliberation are illusions:

"But what if the opposite were true: that he is always living in manifold dependence but regards himself as free when, out of long habituation, he no longer perceives the weight of the chains? It is only from new chains that he now suffers: - 'freedom of will' really means nothing more than feeling no new chains." ${ }^{7-8}$

Nietzsche even argues that the idea of a free will is an invention of the upper strata to fool the lower strata, hoping in vain for social change. Yet, when people maximizing the will to power would at every moment, they face choices about how to do that, meaning alternatives as well as freedom to choose. Nietzsche is not as coherent as Kierkegaard.

Nietzsche had some 15 years of active output of texts, books and pamphlets, poems and aphorisms. A critique of Christianity is to be found in almost all books, or booklets except his first book, The Birth of Tragedy. It may be pointed out that Nietzsche's style evolved or changed over time, becoming more high strung and impatient. His self-biography Ecce $\mathrm{Homo}^{7}$ is so arrogant that one may raise the question of megalomania.

The genius of Nietzsche resides to a large degree in his dexterity to write as well as to choose titles. He comes back to his themes very often, but in a new context. Often his style is paradoxical, but the messages can most often be distilled. Nietzsche propagates a certain set of tenets in almost all books and booklets, although the various versions of these tenets are given different formulation, sometimes with a risk of being incoherent. He mixes these tenets in several ways, sometimes bringing them up abruptly. "Also Sprach Zarathustra" is too special to be included here, showing Nietzsche's mastery of German language. We have not been able to confirm anything real about this prophet: life, dates, texts.

\section{Nietzsche's transformation of all values}

Nietzsche's moral philosophy has two sides, one negative in the form of rejection of established values, and another positive as a reinvigoration of old time values.

\section{The negative message}

The targets of his attacks, often repeated in book after book, are not only the Church institutions, but Christianity as such, socialism and liberalism.

\section{Rejection of Christian morality}

Nietzsche writes:

"But it was not stable enough to withstand the most corrupt type of corruption, to withstand Christians ... This secretive worm that crept up to every individual under the cover of night, fog, and ambiguity and sucked the seriousness for true things, the instinct for reality in general right out of every individual, this cowardly, feminine, saccharine group gradually alienated the 'souls' from that tremendous structure, - those valuable, those masculine-noble natures that saw Rome's business as their own business, their own seriousness, their own pride. ${ }^{7-8}$

What is maybe stunning is the thesis that Nietzsche really maintains that:

i) Christianity is Judaism reinvented or falsified by St. Paul;

ii) Christianity is nothing by a giant moral reversal of good and bad;

iii) Christianity is the slave moral, enslaving civilizations, like the Ancient Roman and present European.

The fall of Rome to Christianity is the well-known argument by historian Edward Gibbons. ${ }^{8}$ But it is so contested and challenged by other theories about the fall of the Roman. Numerous hypotheses have been put forwards: invasions by Barbarian tribes, economic troubles and over-reliance on slave labour, the rise of the Eastern Empire, overexpansion and military overspending, government corruption and political instability, the arrival of the Huns and the migration of the Barbarian tribes, Christianity and the loss of traditional values and the weakening of the Roman legions. In addition, one may mention the theory of a basic shift in economic system, from commerce and trade to serf labour and self-sufficiency, anticipating the feudalisation of the economy and social relationships. The economic system hypothesis was anticipated by Max Weber ${ }^{9}$ and fully famously developed by Rostovtzeff. ${ }^{10}$

\section{Rejection of envy: resentment against moral superiority}

The resentment idea of Nietzsche may be interpreted as the envy or hatred against moral superiority:

"In an even more decisive and profound sense than then, Judea once again triumphed over the classical ideal with the French Revolution: the last political nobility in Europe, that of the French seventeenth and eighteenth centuries, collapsed under the ressentiment-instincts of the rabble, - the world had never heard greater rejoicing and more uproarious enthusiasm! True, the most dreadful and unexpected thing happened in the middle: the ancient ideal itself appeared bodily and with unheard-of splendour before the eye and conscience of mankind, and once again, stronger, simpler and more penetrating than ever, in answer to the old, mendacious ressentiment slogan of priority for the majority, of man's will to baseness, abasement, levelling, decline and decay, there rang out the terrible and enchanting counterslogan: priority for the few!"

Here we come to the crux of the matter analysed in this paper, the valuation of compassion itself. Starting from his deep insight into the teachings of Schopenhauer, his German collegue in philosophy of morality, Nietzsche finds that compassion must lead to negation of life itself. Nietzsche

"dealt especially with the value of the 'unegoistic', the instincts of compassion, self-denial, self-sacrifice which Schopenhauers had for so long gilded, deified and transcendentalized until he was finally left with them as those 'values as such' on the basis of which he said 'no'to life and to himself as well. But against these very instincts I gave vent to an increasingly deep mistrust, a scepticism which dug 
deeper and deeper! Precisely here I saw the great danger to mankind, its most sublime temptation and seduction - temptation to what? to nothingness? - precisely here I saw the beginning of the end, standstill, mankind looking back wearily, turning its will against life, and the onset of the final sickness becoming gently, sadly manifest: ${ }^{11}$

\section{Accusation of slave morals and its rejection}

Nietzsche's slave insurrection tenet goes like this:

"...the Jews performed the miracle of the inversion of valuations, by means of which life on earth obtained a new and dangerous charm for a couple of millenniums. Their prophets fused into one the expressions 'rich,' 'godless,' 'wicked,' 'violent,' 'sensual,' and for the first time coined the word 'world' as a term of reproach. In this inversion of valuations (in which is also included the use of the word 'poor' as synonymous with 'saint' and 'friend') the significance of the Jewish people is to be found; it is with them that the SLAVE INSURRECTION IN MORALS commences." "12-14

But he mixes this debasement of the Jewish people with positive comments that must be underlined here:

\section{No antisemitism}

In this remarkable quotation, Nietzsche rejects some anti-Semitic proposal that he made in other texts. Interesting!

"Incidentally: the entire problem of the Jews exists only within national states, In as much as it is here that their energy and higher intelligence, their capital in will and spirit accumulated from generation to generation in a long school of suffering, must come to preponderate to a degree calculated to arouse envy and hatred, so that in almost every nation-and the more so the more nationalist a posture the nation is again adopting-there is gaining ground the literary indecency of leading the Jews to the sacrificial slaughter as scapegoats for every possible public or private misfortune."

"Moreover: in the darkest periods of the Middle Ages, when the cloudbanks of Asia had settled low over Europe, it was the Jewish freethinkers, scholars and physicians who, under the harshest personal constraint, held firmly to the banner of enlightenment and intellectual independence and defended Europe against Asia; it is thanks not least to their efforts that a more natural, rational and in any event unmythical elucidation of the world could at last again obtain victory and the ring of culture that now unites us with the enlightenment of Graeco-Roman antiquity remain unbroken. If Christianity has done everything to orientalize the occident, Judaism has always played an essential part in occidentalizing it again: which in a certain sense means making of Europe's mission and history a continuation of the Greek." $" 12-14$

We have now documented extensively that the three negative tenets by Nietzsche are not accidental but often repeated as his fundamental civilization convictions. This is Nietzsche's nihilism.

Some of these tenets sit well with the philosophy of modernism, while others are central in post-modernist thinking. Nietzsche's secularism anticipates modernism's a-religiosity or atheism. His attack on envy and equalization can be heard in post-modernism's call for self-realization and human self-fulfillment. His high esteem of the Renaissance and low esteem of Oriental despotism are in accordance with both modernism and post-modernism. Perhaps he is the father of existentialism and subjectivism or individualism without mysticism -liberation from idols?

\section{The positive message}

Nietzsche was not merely a great nihilist, rejecting certain moral philosophies. He also preached a moral of his own making.

\section{Need of large social stratification}

Few social systems are comparable to the India case system in terms of ugliness. Yet, Nietzsche raises no objection, although he is, as usual well-informed in old Indian culture and language. Here, we come to the so-called "Arayan myth", which evidently Nietzsche believed in, no compassion with the "chandalas" and their suffering:

"Let us consider the other method for "improving" mankind, the method of breeding a particular race or type of man. The most magnificent example of this is furnished by Indian morality, sanctioned as religion in the form of "the law of Manu." Here the objective is to breed no less than four races within the same society: one priestly, one warlike, one for trade and agriculture, and finally a race of servants, the Sudras. Obviously, we are no longer dealing with animal tamers: a man that is a hundred times milder and more reasonable is the only one who could even conceive such a plan of breeding. One breathes a sigh of relief at leaving the Christian atmosphere of disease and dungeons for this healthier, higher, and wider world. How wretched is the New Testament compared to Manu, how foul it smells!"

The Indian caste system is forbidden in the modern constitution of the county, with Nietzsche's endorsement of social harassment of the untouchables -"chandala" in Sanskrit, as total. This is written by a man desperately seeking healing against terrible deceases.

\section{Irrelevance of compassion: no merci}

Compassion is not entirely unknown to Nietzsche, as he here confirms that religion may be necessary for living with pain and sufferings. But it is all make belief:

"Religion, and the meaning religion gives to life, spreads sunshine over such eternally tormented people and makes them bearable even to themselves. It has the same effect that an Epicurean philosophy usually has on the suffering of higherranks: it refreshes, refines, and makes the most of suffering, as it were. In the end it even sanctifies and justifies. Perhaps there is nothing more venerable about Christianity and Buddhism than their art of teaching even the lowliest to use piety in order to situate themselves in an illusory higher order of things, and in so doing stay satisfied with the actual order, in which their lives are hard enough (in which precisely this hardness is necessary!)."12-14

Yet, Nietzsche quickly retreats from his compassion. He clearly identifies with the strong and noble against the unlucky and downtrodden:

"They try to preserve, to keep everything living that can be kept in any way alive. In fact, they take sides with the failure as a matter of principle, as religions of the suffering. They give rights to all those who suffer life like a disease, and they want to make every other Feeling for life seems wrong and become impossible.

Whatever merit we Might find in this indulgent, preserving care, which was and is meant for

The highest types of people (since these are the ones that, historically, have

Almost always suffered the most), along with everyone else nevertheless,

In the final analysis, the religions that have existed so far (which have all 
Been sovereign) has played a principal role in keeping the type "man" on

a lower level. They have preserved too much of what should be destroyed." $7-8$

\section{Priority of egoism}

In theories of social justice, it is a necessary condition that justice implies the "impartial spectator" (Sen). But Nietzsche put egoism first, the enlightened selfishness of the noble:

"And the noble soul honors itself in them and in the rights that it gives them; it has no

doubt that the exchange of rights and honors belongs to the natural state

of things too, as the essence of all interaction. The noble soul gives as it

takes, out of the passionate and sensitive instinct of retribution that is so

fundamental to it. The concept of "mercy" is senseless and noisome inter

pares $; \square$ there might be a sublime way of letting gifts fall down on you from

above, as it were, and lapping them up like raindrops; but the noble soul

has no talent for this art and conduct. Its egoism gets in the way: it does

not generally like looking "upwards," - but rather ahead, horizontally and

slowly, or downwards: - it knows that it is high up.—*12-14

The concept of mercy is central in moral philosophy, just like pity. Thus, Johan Rawls formulates his famous second principle of justice: to give priority to less well-off (maximin).Compassion is at the basis of the modern theory of liberal egalitarianism, where equality among men and women has the same value as freedom. Equality is said to result from an impartial consideration of life opportunities for all people. Impartiality is justice, declares philosopher Brian Barry.

But Nietzsche is partial in favour of those on the top:

"Genius and the ideal state in conflict-The Socialists demand a comfortable life for the greatest possible number. If the lasting house of this life of comfort, the perfect State, had really been attained, then this life of comfort would have destroyed the ground out of which grow the great intellect and the mighty individual generally, I mean powerful energy. Were this State reached, mankind would have grown too weary to be still capable of producing genius. Must we not hence wish that life should retain its forcible character, and that wild forces and energies should continue to be called forth afresh? But warm and sympathetic hearts desire precisely the removal of that wild and forcible character, and the warmest hearts we can imagine desire it the most passionately of all, whilst all the time its passion derived its fire, its warmth, its very existence precisely from that wild and forcible character; the warmest heart, therefore, desires the removal of its own foundation, the destruction of itself,- - that is, it desires something illogical, it is not intelligent." ${ }^{9-8}$

Nietzsche succeeds in this passage to reject both classical liberalism (Bentham's formula "Greatest happiness principle") and socialism that focuses upon the state. Both these ideologies are selfdestructive.

\section{Elitism instead of liberalism or socialism}

For Nietzsche, the state has other objectives than the overall welfare of its citizens. Perhaps "the greatest intellect" needs democratic control of the by the poor intellects?! He says:

"Culture and caste - A higher culture can only originate where there are two distinct castes of society: that of the working class, and that of the leisured class who are capable of true leisure; or, more strongly expressed, the caste of compulsory labour and the caste of free labour. The point of view of the division of happiness is not essential when it is a question of the production of a higher culture; in any case, however, the leisured caste is more susceptible to suffering and suffer more, their pleasure in existence is less and their task is greater. Now supposing there should be quite an interchange between the two castes, so that on the one hand the duller and less intelligent families and individuals are lowered from the higher caste into the lower, and, on the other hand, the freer men of the lower caste obtain access to the higher, a condition of things would be attained beyond which one can only perceive the open sea of vague wishes. Thus speaks to us the vanishing voice of the olden time; but where are there still ears to hear it?"

\section{Endorsement of force}

Nietzsche declares:

"What stood as aere perennius, the imperium Romanum, the most magnificent form of organization ever to be achieved under difficult conditions, compared to which everything before or after has just been patched together, botched and dilettantish, those holy anarchists made a 'piety' out of destroying 'the world', which is to say the imperium Romanum, until every stone was overturned, - until even the Germans and other thugs could rule over it..."”

As a stunningly young professor of ancient Greek language at the University of Basel, Nietzsche praised Greek culture until he later too aversion against the couple Socrates-Plato, developing into a phobia with Nietzsche. He said positive things about the Pre-Socrates (Heracleitos) and sometimes also the Post-Socrates (the Eleats). But his greates admiration was for the force of the Roman Emprire:

"The imperiuschem Romanum that we know, that we are coming to know better through the history of the Roman provinces, this most remarkable artwork in the great style was a beginning, its design was calculated to prove itself over the millennia, -, nothing like it has been built to this day, nobody has even dreamed of building on this scale, sub specie aeternity-This organization was stable enough to hold up under bad emperors: the accident of personalities cannot make any difference with things like this,-first principle of all great architecture." $7-8$

The resentiment idea of Nietzsche is his hatred of ideas arguing against moral superiority, with the Romans or with elites threated by social revolution:

$+\ldots$ Judea once again triumphed over the classical ideal with the French Revolution: the last political nobility in Europe, that of the French seventeenth and eighteenth centuries, collapsed under the ressentiment-instincts of the rabble,- the world had never heard greater rejoicing and more uproarious enthusiasm! True, the most dreadful and unexpected thing happened in the middle: the ancient ideal itself appeared bodily and with unheard-of splendour before the eye and conscience of mankind, and once again, stronger, simpler and more penetrating than ever, in answer to the old, mendacious ressentiment slogan of priority for the majority, of man's will to baseness, abasement, levelling, decline and decay...." ${ }^{\prime-17}$

Modern democracy coming during Nietzsche's life time is 
interpreted as also with resentiment hypothesis, stemming historically ultimately from Christianity and Buddhism.

\section{Admiration of violence: Roman Empire}

Nietzsche was well aware of Greek superiority over the Romans in certain important domains of culture. We read:

"Rather they quickly replaced them with what was contemporary and Roman. They seem to ask us: 'Should we not make new for ourselves what is old and put ourselves into it?

Should we not be allowed to breathe our soul into their dead body? For

it is dead, after all: how ugly everything dead is!' They did not know the

pleasure of a sense for history; what was past and alien was embarrassing

to them; and as Romans, they saw it as an incentive for a Roman

conquest. In faet at that time one conquered by translating - not merely

by leaving out the historical, but also by adding allusions to the present

and, above all, crossing out the name of the poet and replacing it with

one's own - not with any sense of theft but with the very best conscience

of the imperium Romanum." ${ }^{12-14}$

If Roman culture is merely a copy of Greek literature and philosophy, then where does its superiority reside? Reply: In Gaius Julius Ceasar-the total personification of force and violence, for whom Nietzsche had unrestrained admiration, despite his genocide in Gaul that he enslaved for incredible personal fortune. ${ }^{15-29}$

\section{Balance between Subjectivity and Objectivity: Rejection of perspectivism}

While Kierkegaard maintains a fine balance between the subjective and the objective in human knowledge, Nietzsche pursues his perspectivism to total subjectivism. Consider the following sentences:

(F) There are no facts;

(N) It is a fact that Nietzsche says "there are no facts".

If $(\mathrm{F})$ is true, than $(\mathrm{N})$ is not true; and if $(\mathrm{N})$ is true, then $(\mathrm{F})$ is not true. A theory that speaks about everything speaks about nothing. General perspectivism with Nietzsxhe and post-modernism is flawed. Any philosophy interpreting the human condition today faces the undeniable facts:

(a) The universe comprises trillions of suns and planets, of which one is Planet Earth;

(b) Planet Earth is under the terrible threat of climate change, involving the real possibility of human extinction.

Governments and civil society can do something to halt global warming or let things just evolve: Either - Or, with Kierkegaard.

\section{Conclusion}

One may say that Kierkegaard and Nietzsche had one thing income, namely reflection over the question of individual identity: How to become the person you really are? This micro focus was not explored in German idealism, speculating about macro determinism, ${ }^{30-35}$ nor did it fit into Kantian rationalism, looking into a super reason for constructing the world of phenomena and of morality. Here is their anticipation of existentialism with its micro focus on personal responsibility. Here, they are forerunner of individual psychology, in order to unravel the real forces that drive humans.

Yet, the difference between Kierkegaard and Nietzsche remain large, as the former emphasized the freedom of the will and individual decision-making, whereas Nietzsche could not free himself from historicism in the form of Christianity (negative) and Roman valour (positive).

\section{Acknowledgements}

None.

\section{Conflict of interest}

Author declares there is no conflict of interest.

\section{References}

1. Anderson R Lanier. "Friedrich Nietzsche", The Stanford Encyclopaedia of Philosophy. Edward N Zalta, editor. 2017.

2. Dutta P. Games and Strategies. Cambridge, MA: MIT Press; 1999.

3. Garff J. Soren Kierkegaard.A biography. Princeton: Princeton UP; 1994.

4. Stewart J. A Companion to Kierkegaard. Oxford: Wiley-Blackwell. 2015.

5. Kierkegaard S. Either-Or. Princeton: Princeon UP; 1944;138:146.

6. Kierkegaard S, Journalen JJ. (1843), Søren Kierkegaards Skrifter, Copenhagen, 1997;18:306.

7. Nietzsche F. The Anti-Christ, Ecce Homo, Twilight of the Idols. In: Ridley A, Norman J, editors. Cambridge: Cambridge UP; 2005.

8. Nietzsche F. Human, all too human. Schacht R, editor. Cambridge: Cambridge UP; 1996.

9. Gibbon E, Trevor-Roper H. The Decline and fall of the Roman Empire $W \& N$. Abridged Ed edition. 2005.

10. Weber M. Agrarian Sociology of Ancient Civilizations. London: Verso; 2013.

11. Rostovtzeff M. The Social \& Economic History of the Roman Empire. Oxford: PM Fraser; 1957.

12. Nietzsche F. On the Genealogy of Morals. Ansell-Person K, editor. Cambridge: Cambridge UP; 2006.

13. Nietzsche F. Beyond Good and Evil. In: Horstman RP, Norman J, editors. Cambridge: Cambridge UP; 2000.

14. Nietzsche F. The Birth of Tragedy. In: Guess R. and R. Spears, editors. Cambridge: Cambridge UP; 1999.

15. Magnus B, Higgins K. The Cambridge Companion to Nietzsche. Cambridge: Cambridge UP; 1996.

16. Sen A. The Idea of Justice. Cambridge: Harvard UP; 2009.

17. Tanner M. Nietzsche: A Very Short Introduction. Oxford: Oxford UP; 2000.

18. Young J. Friedrich Nietzsche: A Philosophical Biography. Cambridge: Cambridge UP; 2010.

19. Nietzsche F. Daybreak. In: Clark M, Leiter B, editors. Cambridge: Cambridge UP; 1997.

20. Nietzsche F. The Gay Science. Williams B, editor. Cambridge: Cambridge UP. 2001.

21. Frank H Wallis. Roman Scandal: A Brief History of Murder, Adultery, Rape, 
Slavery, Animal Cruelty, Torture, Plunder, and Religious Persecution in the Ancient Empire of Rome. Create Space Independent Publishing. 2016

22. Juvenal. The Sixteen Satires. Penguin; 1998.

23. Roland Auguet. Cruelty and Civilization: The Roman Games. Routledge; 2012.

24. Paul Erdkamp. The Cambridge Companion to Ancient Rome. Cambridge University Press. 2013.

25. Melissa Barden Dowling. Clemency and Cruelty in the Roman World. Niversity of Michigan Press; 2000.

26. Patricia Southern. The Roman Army: A History 753BC-AD476. Amberley Publishing. 2016.

27. David J Mattingly. Imperialism, Power, and Identity: Experiencing the Roman Empire. Princeton: Princeton UP; 2013.

28. Weber M. Ancient Judaism. New York: Simon and Schuster. 1967.
29. McDonald, W. "Søren Kierkegaard". The Stanford Encyclopedia of Philosophy. Edward N Zalta, editor. 2017.

30. Kierkegaard S. Concept of Anxiety: A Simple Psychologically Orienting Deliberation on the Dogmatic Issue of Hereditary Sin. Princeton: Princeton UP; 1981.

31. Kierkegaard S. Concluding Unscientific Postscript to Philosophical Fragments. In: Swenson DF, Lowrie W, editors. Princeton: Princeton University Press; 1992.

32. Kierkegaard S. Fear and Trembling: Dialectical Lyric by Johannes De Silentio. London: Penguin; 1986.

33. Kierkegaard S. Philosophical Fragments/Johannes Climacus: Kierkegaard's Writings. Princeton: Princeton UP; 1985.

34. Stewart J. A Companion to Kierkegaard. Oxford: Wiley-Blackwell. 2015.

35. Safranski R. Nietzsche: Biographie seines Denkens. Frankfurt am Main: Fisher. 2002. 